\title{
PENGGUNAAN SYSTEM THINKING PADA PERUSAHAAN PT SAMPUL KREATIF TEKNOLOGI
}

\author{
H.A. Farisi ${ }^{1}$, M. Rizal ${ }^{2}$, R. Arifiantit ${ }^{3}$ \\ 1,2,3 Administrasi Bisnis, Universitas Padjadjaran, Bandung \\ e-mail : hasan20002@mail.unpad.ac.id, muhamad.rizal@unpad.ac.id, r.arifianti@unpad.ac.id
}

\begin{abstract}
Abstrak
Kompleksitas permasalah bisnis dalam organisasi perusahaan kerap kali menjadi problematika yang tidak dapat dihindari bagi pelaku bisnis, ada banyak faktor yang menyebabkan permasalahan terjadi namun permasalah tersebut dapat dihindari dengan mengimplementasikan system thinking sebagai salah satu solusinya. Metode system thinking diterapkan untuk menghubungkan elemen-elemen sistem menjadi kesatuan untuk mencapai tujuan organisasi. System thinking diterapkan untuk memenuhi kebutuhan organisasi dalam penyelesaian masalah, penentuan solusi dan memprediksi keberlangsungan organisasi di masa yang akan datang. Tujuan penelitian ini untuk memaparkan pengaruh penggunaan system thinking pada organisasi perusahaan konsultan dengan metode studi deskriptif menggunakan studi literatur untuk mengambil data. Hasil yang didapatkan adalah metode system thinking yang diterapkan di perusahaan PT Sampul Kreatif Teknologi untuk aktivitas bisnis organisasi menjadi efektif dalam menghasilkan keuntungan untuk mencapai tujuan.
\end{abstract}

Kata kunci: System Thinking, Perusahaan Konsultan, Keberlangsungan Perusahaan

\begin{abstract}
The complexity of business problems in corporate organizations often becomes an unavoidable problem for business people, there are many factors that cause problems to occur but these problems can be avoided by implementing systems thinking as one of the solutions. The system thinking method is applied to connect system elements into a unit to achieve organizational goals. Systems thinking is applied to meet the needs of the organization in solving problems, determining solutions and predicting the sustainability of the organization in the future. The purpose of this study is to describe the effect of using systems thinking on consulting firm organizations with a descriptive study method using literature studies to collect data. The results obtained are the system thinking method applied in PT Sampul Kreatif Teknologi for the organization's business activities to be effective in generating profits to achieve goals.
\end{abstract}

Keywords: System Thinking, Consulting Firm, Company Sustainability

\section{Pendahuluan}

Menurut (Kuswarno, 2001; Rogers, 1976) Organisasi dapat diartikan sebagai suatu sistem individu yang relatif stabil yang bekerja sama untuk mencapai tujuan Bersama melalui struktur hierarki dan pembagian kerja. Tata hubungan di antara anggota organisasi relatif stabil; kestabilan susunan organisasi menjadikan organisasi berfungsi secara efektif dalam mencapai tujuannya. Sifat dari sebuah organisasi adalah memiliki tujuan yang harus dicapai oleh setiap anggotanya. Akibat adanya tujuan organisasi maka strategi, aturan dan cara-cara untuk mencapai tujuan tersebut diciptakan dan dikembangan sebagai suatu komponen penting di dalam tubuh organisasi. Perusahaan adalah salah satu jenis dari organisasi yang bertujuan untuk memperoleh pendapatan /outcome /keuntungan yang maksimal, sehingga kegiatan difokuskan untuk produksi dan mendistribusikan barang/jasa secara optimal.

Di negara Indonesia, perusahaan dibedakan menjadi beberapa tingkatan berdasarkan besaran pendapatan yang dapat mereka hasilkan, tingkatan ini dibagi menjadi perusahaan mikro, kecil dan menengah (UMKM). Berdasarkan hasil survey data Kementerian Koperasi UMKM tahun 2018 di Indonesia, bahwa UMKM memiliki peranan penting dalam perkembangan perekonomian negara sehingga menjadi tolak ukur terhadap kesejahteraan perekonomian masyarakat. Oleh 
karena itu UMKM di Indonesia harus dipelihara keberlangsungannya karena kontribusi yang diberikan terhadap perkembangan perekonomian cukup besar. Walaupun jumlah dan perkembangan UMKM di Indonesia tergolong banyak, namun bukan berarti hal itu mengesampingkan permasalah yang terjadi di dalam tubuh UMKM itu sendiri. Banyak pelaku bisnis UMKM yang menciptakan bisnisnya namun berakhir dengan kegagalan dalam kurun waktu yang tidak lama. Oleh karena itu penting kiranya bagi pelaku bisnis untuk membuat perencanaan dan pemeliharaan yang tepat demi menjaga keberlangsungan bisnisnya guna memberikan kontribusi yang besar terhadap perkembangan perekonomian Negara. Salah satu cara menjaga keberlangsungan UMKM adalah dengan pengembangan dan pemeliharan sistem yang baik. Menurut hasil survei yang dilakukan terhadap 320 chief executive, chief operating officer dan perencana strategis yang tercantum di dalam buku Analisis \& perancangan sistem informasi untuk keunggulan bersaing perusahaan \& organisasi modern yang dikarang oleh (AI Fatta, 2007) menunjukkan bahwa sistem merupakan faktor utama yang integral dalam perusahaanperusahaan di Amerika. Hasil survey memperlihatkan bahwa top eksekutif percaya bahwa sistem memegang peranan penting pada semua lini perusahaan. Para eksekutif yakin bahwa sistem merupakan sumber daya strategis untuk kegiatan mereka. Walaupun hasil penelitian dilakukan terhadap perusahaan-perusahaan Amerika namun sektor bisnis yang dijalankan tidak memiliki perbedaan dengan negara lainnya termasuk Indonesia. Menurut (Al Fatta, 2007) juga secara sederhana sistem diartikan sebagai suatu kumpulan atau himpunan dari unsur atau variablevariabel yang saling terorganisasi, saling berinteraksi dan saling bergantung satu sama lain. Senada dengan analisis yang dilakukan oleh Al Fatta, berdasarkan hasil dari penelitian sebelumnya yang memiliki kaitan dengan penelitian saat ini menunjukkan bahwa kontribusi penggunaan sistem yang baik akan menghasilkan kinerja yang lebih baik, penelitian-penelitian tersebut diantaranya adalah penelitian (Suaryana, 2014) yang memberikan kesimpulan berupa hasil bahwa sistem akuntansi mempengaruhi kinerja individu secara positif. Kemudian penelitian (Prastika \& Purnomo, 2019) yang menghasilkan kesimpulan bahwa sistem akuntansi berpengaruh baik pada kinerja pengrajin perak. Terakhir ada penelitian (Imbayani \& Endiana, 2016) hasilnya, Kinerja UMKM menghasilkan peningkatan yang positif akibat pemahaman sistem informasi yang baik. Oleh karena itu dapat ditarik kesimpulan bahwa pemahaman dan penerapan sistem yang baik dapat mempengaruhi kinerja dan tercapainya tujuan perusahaan, artinya secara tidak langsung perusahaan sedang membangun sebuah elemen-elemen yang saling menyatu untuk mewujudkan tujuannya. Berlawanan dengan sistem yang baik, sistem yang buruk hanya akan menjadi salah satu sebab keberlangsungan bisnis perusahaan tidak bertahan lama. Menurut (Al Fatta, 2007) terdapat lima ciri sistem yang buruk yaitu 1). Tidak memenuhi pengguna. 2). Performa buruk. 3). Reliabilitas rendah. 4). Kegunaan rendah dan terakhir 5). Tidak ada rencana anggaran dan memungkinkan over budget. Maka pantaslah jika keberlangsungan bisnis dipertaruhkan apabila tidak memperhatikan sistem yang dipergunakannya.

Sebagai sesuatu yang penting dalam perkembangan dan keberlangsungan bisnis perusahaan, muncullah berbagai macam jenis sistem, salah satunya adalah system thinking atau pemikiran sistem. Menurut (Schoderbek, 1980) system thinking adalah sebuah kajian yang digunakan untuk dapat mengumpulkan elemen-elemen yang ada di dalam sistem menjadi sebuah kesatuan untuk bersama-sama mencapai tujuan yang telah ditentukan. System thinking memiliki beberapa nilai positif yaitu mengobservasi sebuah objek penelitian menjadi lebih mendalam, memandang segala sesuatu dalam arti bisnis sebagai suatu sistem, mampu diterapkan untuk memetakan permasalah dengan jernih, mengidentifikasi titik kritis, formulasi kebutuhan dan yang terpenting adalah sebagai dasar penyusunan kebijakan, strategi dan rencana aksi.

Pemikiran sistem atau system thinking sudah diterapkan diberbagai macam sektor bisnis UMKM, salah satunya adalah perusahaan PT Sampul Kreatif Teknologi yang merupakan perusahaan mikro yang bergerak di sektor teknologi yang kini berlokasi di Jawa Barat. Perusahaan PT Sampul Kreatif Teknologi sudah berdiri sejak tahun 2014 dan hingga kini 
perusahaan semakin bertumbuh dan berkembang dengan jumlah pegawai mencapai puluhan orang. Ditengah persaingan bisnis yang semakin ketat, perusahaan PT Sampul Kreatif Teknologi masih dapat bertahan dan terus mengembangkan dirinya. Salah satu tujuan dari penelitian ini adalah untuk mengidentifikasi keberadaan system thinking di perusahaan PT Sampul Kreatif Teknologi, bagaimana penggunaannya di dalam kegiatan perusahaan dan melakukan pengukuran sistem agar dapat menentukan seberapa besar pengaruh system thinking terhadap efektifitas perusahaan untuk mencapai tujuan. Perusahaan PT Sampul Kreatif Teknologi menjadi objek penelitian karena dilandasi oleh sejarah perkembangan perusahaan yang telah melalui banyak rintangan namun dapat bertahan hingga saat ini. Hal inilah yang menjadi menarik tatkala ketika banyak perusahaan UMKM sejenis yang mengalami kebangkrutan akibat ketidakmampuan mereka menghadapi kerasnya tantangan bisnis. Maka karena itu pemilihan PT Sampul Kreatif Teknologi dapat menjadi contoh bagi UMKM lainnya dalam menggunakan, mengembangkan dan mempertahankan sistem.

Di dalam kajian system thinking terdapat dua komponen utama yang menjadi titik kritis untuk dianalisis diantaranya sistem dan suprasistem. Kedua komponen tersebut dibedakan berdasarkan tingkat pengendaliannya. Menurut (Schoderbek, 1980) Sistem di dalam tubuh organisasi adalah suatu komponen yang dapat dikendalikan sedangkan suprasistem adalah komponen yang tidak dapat dikendalikan namun memiliki pengaruh yang besar terhadap keberlangsungan bisnis. Berikut adalah arsitektur system thinking.

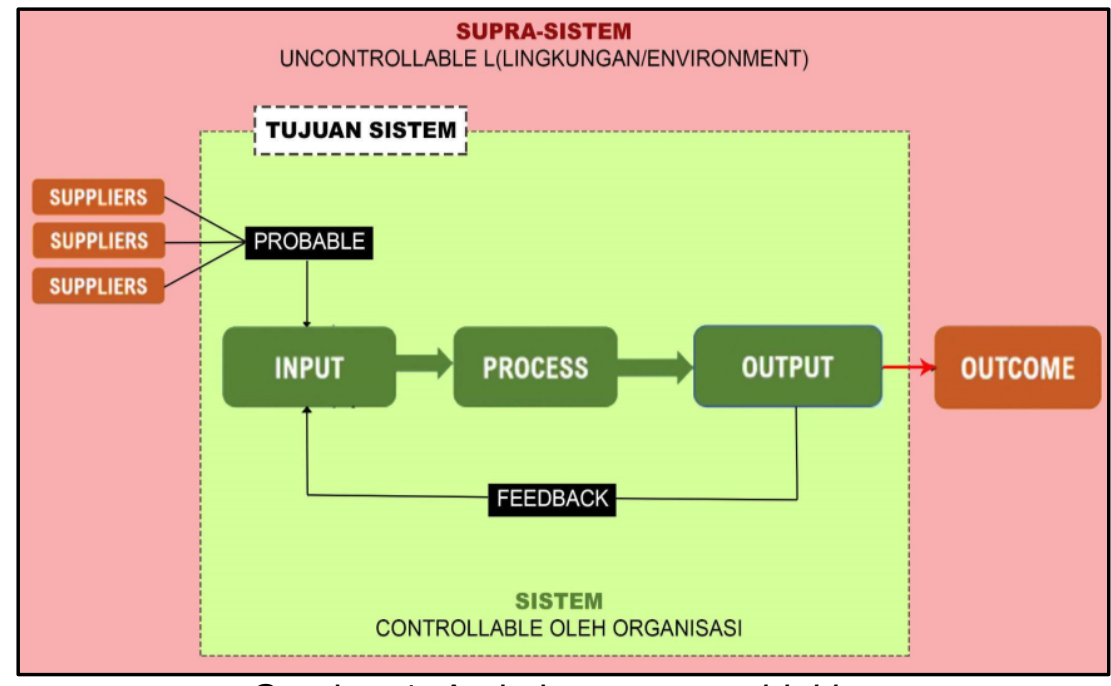

Gambar 1. Arsitektur system thinking

Gambar 1 menunjukkan adanya pola ketergantungan antara sistem dan suprasistem yang mempengaruhi konsumen, hal ini ditunjukan oleh kolom hijau yang menandakan sistem terkontrol dimana pelaku bisnis dapat mengatur sendiri kegiatan usahanya dan ada pula suprasistem yang ditunjukan dengan warna merah yang mempengaruhi kegiatan usaha sehingga konsumen dapat memperoleh produk yang telah dihasilkan oleh perusahaan. Menurut (Schoderbek, 1980) bahwa sebuah organisasi dapat dikatakan memiliki sistem apabila memiliki ciri-ciri berikut, diantaranya (1) Tujuan dan kinerja sistem yang akan dicapai dengan berbagai macam kegiatan yang disebut sebagai aktivitas. (2) Sumber daya sistem yaitu segala cara dan bahan yang tersedia baik SDA/SDM yang digunakan oleh sistem untuk mencapai tujuan dikatakan sebagai resources. (3) Adanya misi, kegiatan dan aktivitas yang dilakukan oleh sistem agar tercapainya sebuah tujuan. (4) Pengelolaan organisasi melalui perencanaan pada tujuan, penggunaan sumber daya, kegiatan termasuk perencanaan perubahan dan pengalian. (5) Lingkungan sistem/ekosistem segala hal yang berada diluar sistem dikatakan sebagai lingkungan 
atau ekosistem. Sedangkan menurut (Al Fatta, 2007) suatu sistem memiliki karakteristik yang dapat membedakan suatu sistem dengan lainnya yaitu (1) Memiliki Batasan dari suatu elemen atau unsur yang termasuk di dalam sistem dan mana yang berada di luar sistem. (2) Lingkungan yaitu segala sesuatu di luar sistem, lingkungan yang menyediakan asumsi, kendala dan input terhadap suatu sistem. (3) Adanya masukan yaitu sumber daya (data, bahan baku, peralatan, energi) dari lingkungan yang dikonsumsi dan dimanipulasi oleh suatu sistem. (4) Adanya keluaran atau output sebagai sumber daya atau produk (informasi, laporan, dokumen, tampilan layer computer, barang jadi) yang disediakan untuk lingkungan sistem oleh kegiatan dalam suatu sistem.

Suatu organisasi memiliki berbagai cara untuk menterjemahkan sistem untuk tujuan organisasi mereka. Menggunakan cara pemanfaatan sumber daya secara maksimal atau melakukan analisis lingkungan tempat berlangsungnya bisnis adalah cara yang lumrah dalam menterjemahkan sistem. Walaupun demikian menurut (AI Fatta, 2007) sistem yang baik adalah sistem yang dapat memberikan pengarahan dan pandangan yang jelas serta mantap mengenai tindakan dan keputusan yang harus diambil oleh organisasi dalam menjalankan bisnis. Memandang segala sesuatu dalam arti bisnis sebagai suatu sistem adalah manfaat lain yang akan diperoleh dalam upaya penerapan sistem, dengan demikian seorang pebisnis akan mampu menentukan strategi, kegiatan dan tindakan dan bahkan meramalkan masa depan organisasinya dari teori sistem yang diimplementasikan. Menurut (Anderson \& Johnson, 1997) menyebutkan bahwa system thinking adalah karakteristik dari sebuah prinsip-prinsip, diantaranya (1) The "Big Picture" yaitu memandang sebuah masalah dengan perspektif yang sempit hanya akan menghasilkan tekanan dan perolehan solusi yang lebih sedikit. System thinking mengajarkan akan adanya pelebaran sudut pandang terhadap masalah-masalah yang dihadapi dengan melihat pada keseluruhan masalah dari bagian sistem terbesar. Perspektif yang lebih luas akan menghasilkan keefektifan solusi. (2) Long term, short term dimana System thinking tidak berbicara akan jangka pendek atau jangka panjang bisnis, karena di dalam system thinking kedua hal tersebut menjadi penting untuk dipertimbangkan dan diimplementasikan. Di dalam system thinking menunjukkan perilaku untuk menuntun pada keberhasilan jangka pendek, karena keberhasilan tersebut akan mendorong kepada keberhasilan jangka panjang. Akan tetapi hal ini bukan semata-mata berbicara "lebih baiknya" memikirkan jangka panjang daripada jangka pendek namun mengkolaborasikan kedua hal tersebut menjadi suatu kesatuan dalam setiap pengambilan keputusan yang telah diambil. (3) Dynamic, Complex and interdependent yaitu ketika melihat sebuah sistematika dunia yang dinamis, komplek dan saling ketergantungan menjadikannya berantakan dan saling terhubung. Ini menjadikan dorongan untuk menyelesaikan masalah atau ketidakpastian masa depan dengan cara yang sangat mudah, mencari jalan pintas atau hanya ingin menyelesaikan satu masalah pada satu waktu saja. Di dalam system thinking adanya pengingat untuk menyederhanakan, menstrukturkan, melinearkan pemahaman berpikir yang memiliki batasan, dan dapat menghasilkan masalah yang dapat dijadikan solusi. Intinya adalah memiliki kepekaan terhadap hubungan sistem baik di dalam organisasi maupun diluar organisasi. Apabila sebuah organisasi sudah menerapkan system thinking yang ditunjukkan dengan ciri-cirinya, maka saatnya untuk melakukan pengukuran. Pengukuran sistem bertujuan untuk mengetahui seberapa besar keefektifan dan keefisienan sebuah sistem apabila diterapkan di dalam organisasi. 


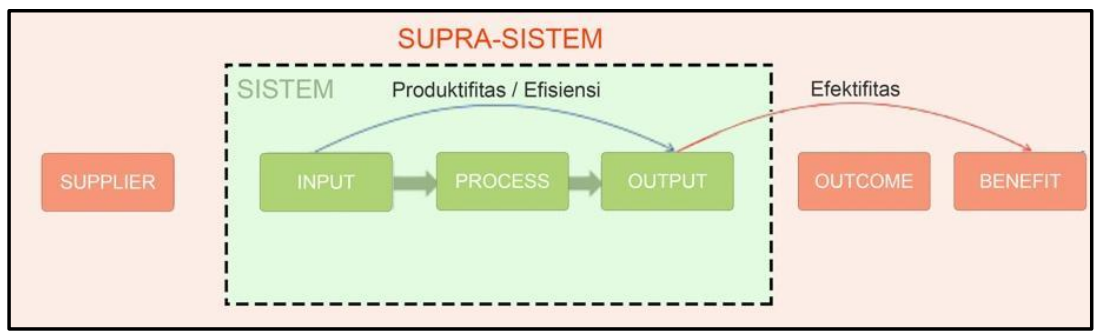

Gambar 2. System Measurement

Menurut (Schoderbek, 1980) Pengukuran sistem dapat dilakukan untuk mengukur aspek-aspek berikut ini diantaranya (1) Produktifitas atau Efektifitas: Mengukur proses masukan hingga hasil keluaran dari kegiatan produksi perusahaan. Contohnya adalah mengukur kualitas bahan-bahan mentah yang diperoleh dari supplier hingga menjadi produk yang siap didistribusikan. (2) Efisiensi yaitu mengukur produk yang telah dihasilkan dari proses produksi hingga akhirnya memperoleh benefit atau profit bagi perusahaan. Contohnya adalah barang yang telah dibeli oleh konsumen dan hasil penjualannya diterima kembali oleh perusahaan. Tujuan dari adanya pengukuran sistem bukan semata-mata untuk mengetahui seberapa berhasilnya perusahaan meraih tujuan, namun lebih daripada itu yaitu untuk mengetahui tingkat pencapaian tujuan suatu sistem, mengetahui efisiensi atau produktivitas suatu sistem lalu digunakan untuk mengetahui titik kritis suatu sistem dan yang terakhir untuk mengukur kerentanan atau ketangguhan suatu sistem terhadap lingkungannya.

Pengukuran sistem salah satu caranya dapat menggunakan metode korelasi parsial. Menurut (Telussa et al., 2013) korelasi parsial yaitu pengukuran yang pengukurannya dilakukan antara satu objek dengan objek lainnya. Korelasi parsial melibatkan variabel bebas yang lebih dari satu dan variabel terkait. Korelasi parsial digunakan untuk mengidentifikasi kuat atau lemahnya hubungan setiap variabel nya.

$$
\tau=\frac{n \sum \chi \gamma-\left(\sum \chi\right)\left(\sum \gamma\right)}{\sqrt{\left\{n \sum \chi^{2}-\left(\sum \chi\right)^{2}\right\}\left\{n \sum \gamma^{2}-\left(\sum \gamma\right)^{2}\right\}}}
$$

$\mathrm{n}=$ Jumlah data

$\mathrm{X}=$ Variabel bebas

$\mathrm{Y}=$ Variabel terikat

Pengambilan kesimpulan dapat dilakukan dengan tabel berikut menurut (Telussa et al., 2013):

Tabel 1. Pengambilan kesimpulan korelasi parsial

\begin{tabular}{ll}
\hline \multicolumn{1}{c}{ Score } & \multicolumn{1}{c}{ Keterangan } \\
\hline $0,00-0,199$ & Korelasi sangat lemah \\
$0,20-0,399$ & Korelasi lemah \\
$0,40-0,599$ & Korelasi sedang \\
$0,60-0,799$ & Korelasi kuat \\
$0,80-1,0$ & Korelasi sangat kuat
\end{tabular}

Apabila pengukuran sistem dapat dilaksanakan dengan baik maka diharapkan akan menghasilkan informasi awal untuk memberikan informasi penting bagi pembuat keputusan, 
kebijakan, strategi hingga tindakan operasional perusahaan. Oleh karena itu pengukuran yang dilakukan setelah adanya sistem yang dibuat serta dijalankan di dalam organisasi menjadi tahapan akhir dalam serangkaian system thinking.

\section{Metode}

Penelitian yang dilakukan oleh penulis termasuk jenis penelitian studi literatur dimana studi ini dimulai dengan mencari sumber-sumber materi yang relevan guna menyelesaikan permasalah yang diangkat di dalam makalah. Studi literatur menggunakan pendekatan penghimpunan datadata dari sumber-sumber yang dapat dipertanggungjawabkan kebenarannya, contoh sumber data yang dijadikan referensi oleh penulis adalah dokumen resmi perusahaan (company profile), website resmi perusahaan sampulkreativ.com dan hasil wawancara dengan narasumber kompeten yang mengetahui seluk beluk perusahaan (direktur utama). Data yang telah diperoleh kemudian dianalisis dengan metode analisis deskriptif untuk mendeskripsikan fakta-fakta yang telah didapat hingga pada akhirnya diuraikan untuk didapatkan pemahaman baru terkait keterhubungannya dengan masalah yang ada sehingga menghasilkan sebuah solusi.

\section{Hasil dan Pembahasan}

Sampul Kreatif adalah salah satu perusahaan pengembang perangkat lunak yang menerapkan teori sistem di dalam menjalankan proses bisnisnya. Sistem menjadi penyebab dari penyusunannya pola (pattern) yang akan menghasilkan event atau kegiatan. Suatu sistem adalah suatu himpunan dari unsur-unsur yang membentuk hubungan-hubungan antar komponen yang memiliki ciri-ciri dan lingkungannya sehingga membentuk suatu kesatuan. Sistem inilah yang diterapkan di dalam perusahaan untuk membentuk suatu kesatuan yang dituliskan dalam visi dan misi perusahaan. Menurut (Schoderbek, 1980) untuk meninjau penerapan sistem di dalam perusahaan, pertama kali dibutuhkan pengidentifikasian sistem berdasarkan ciri-cirinya, oleh karena itu diperlukan penjabaran ciri-ciri system thinking yang dimiliki oleh perusahaan PT Sampul Kreatif Teknologi.

Pertama tujuan dan kinerja yang diartikan sebagai sebuah tujuan (goal) yang dimiliki oleh perusahaan yang menjadi kekuatan penggerak dalam menjalankan bisnis. Tujuan perusahaan dibagi menjadi dua bagian yaitu tujuan Manifes (Sudah dirancang) yang menurut (Abercrombie et al., 2010) adalah tujuan konsekuensi dari tindakan sosial yang diakui dan diniatkan oleh aktor atau lembaga sosial. Biasanya tujuan manifes merupakan tujuan yang sudah jelas dan nyata. apabila disederhanakan yang dimaksud dengan tujuan manifes adalah tujuan nyata yang diharapkan dan fungsional terhadap struktur sosial. Tujuan yang memang sangat diharapkan oleh perusahaan dicantumkan dalam visi perusahaan dan dikukuhkan dalam AD/ART perusahaan, sehingga sifatnya menjadi mutlak dan wajib untuk diwujudkan oleh setiap komponen perusahaan. Kedua adanya tujuan Laten (Tidak terduga) yang dimana menurut (Abercrombie et al., 2010) tujuan laten adalah konsekuensi yang tidak diniatkan, suatu tindakan yang tidak diakui baik dari aktor maupun dalam tindakan sosial. Tujuan laten dapat juga dikatakan sebagai tujuan yang tersembunyi yang tidak diharapkan dalam struktur sosial, namun kehadirannya tidak mengganggu keseimbangan struktur sosial yang diartikan sebagai keberuntungan lingkungan karena sebagian besar tujuan ini dipengaruhi oleh suprasistem atau sistem uncontrollable. Menyikapi tujuan laten, perusahaan menerjemahkannya dengan memilih lingkungan bisnis yang dianggap kondusif contohnya adalah memilih sarana gedung perkantoran sebagai tempat berlangsungnya kegiatan produksi dari pada memilih rumah tempat tinggal yang diubah menjadi kantor. Menurut perusahaan, pemilihan gedung perkantoran dapat memperbesar kesempatan untuk mendapatkan kepercayaan konsumen dan meningkatkan relasi kolega.

Kedua adalah sumber daya untuk menunjang proses bisnis perusahaan diperoleh dari penyeleksian yang ketat guna mendapatkan sumber daya atau pegawai terbaik. Menurut (Sakeon \& Uhing, 2019) keberhasilan perusahaan sangat ditentukan oleh pengetahuan, keterampilan, kerjasama dari beberapa pegawai. Kinerja pegawai yang tinggi sangat diharapkan 
oleh perusahaan karena produktivitas perusahaan secara keseluruhan akan meningkat dan perusahaan dapat bertahan dalam jangka waktu yang panjang dalam persaingan global. Oleh karena itu perusahaan PT Sampul Kreatif Teknologi meyakini hal senada dengan Sekon \& Uhing bahwa keberhasilan mencapai tujuan tidak terlepas dari dukungan pegawai yang mumpuni untuk menjalankan setiap proses bisnis. Perusahaan memiliki beberapa program yang diterapkan dalam memperoleh pegawai terbaik, seperti Program PKL, magang dan kursus bagi siswa atau mahasiswa, program guru tamu dan asesor uji kompetensi sekolah dan tentunya seleksi pegawai menggunakan tes tertulis dan tes komputer sesuai bidang keahlian. Program-program yang diciptakan oleh perusahaan dalam menyeleksi dan membantu peningkatan sumber daya manusia tidak lain bertujuan untuk menghasilkan kinerja produk yang maksimal, hal-hal yang dirasa tidak kompeten untuk mencapai kinerja maksimal maka akan segera dilakukan penataan ulang. Program pemberdayaan sistem di perusahaan diterjemahkan kedalam sistem yang berfungsi untuk mencapai tujuan.

Ketiga adalah komponen sistem yang didalamnya terdapat aktivitas atau kegiatan yang menunjang bisnis. Menurut (Kusmayadi, 2008) Kegiatan bisnis perlu dilandasi oleh sebuah kebijakan perusahaan yang bersifat kompetitif atau berorientasi untuk mencapai keunggulan bersaing di masa yang akan datang. Pola strategi yang spesifik dan memadai perlu dilakukan karena adanya persaingan yang semakin ketat. Pola tersebut harus dapat menampung perubahan-perubahan yang terjadi dilingkungan bisnis dimasa yang akan datang. Perusahaan PT Sampul Kreatif Teknologi menerjemahkan kegiatan bisnis dengan menerapkan aturan-aturan dan kebijakan sebagai proses yang ketat namun fleksibel. Hal ini ditunjukkan dengan adanya sistem kehadiran, sistem pencatatan lembur dan indek performa pegawai. Elemen sistem tersebut menghasilkan kegiatan yang wajib untuk dilakukan oleh setiap komponen perusahaan. Walaupun demikian, perusahaan tidak segan-segan memberikan apresiasi kepada pegawaipegawainya dengan memberikan tunjangan-tunjangan di luar tunjangan wajib (gaji) demi kesejahteraan, salah satu contohnya adalah kegiatan berlibur bersama (outing), makan siang atau malam bersama dan olahraga wajib bersama.

Keempat adalah adanya lingkungan (environment), walaupun lingkungan tidak menjadi fokus utama dalam menjalankan bisnis perusahaan, namun tidak dipungkiri jika lingkungan memiliki peranan yang besar bagi keberhasilan tujuan yang dimiliki oleh perusahaan. Menurut (Hunger, 2020) lingkungan bisnis (business environment) memiliki pengaruh yang kuat terhadap perusahaan, terlebih ketika kondisi dunia yang tidak terbatas lagi oleh teritorial negara (borderless world), perubahan fundamental berdampak terhadap kebijakan yang akan diambil oleh perusahaan. Berikut adalah faktor umum yang mempengaruhi sistem, seperti pertumbuhan ekonomi nasional yang dapat mempengaruhi kegiatan bisnis perusahaan, di dalamnya terdapat faktor adat, agama dan kebiasaan. Kedua karena saat ini perusahaan sudah melakukan kerja sama dengan beberapa instansi luar negeri dalam mengembangkan bisnisnya, dan perkembangan teknologi informasi serta teknis pengembangan aplikasi menjadi faktor selanjutnya maka setiap komponen perusahaan dituntut harus mampu untuk mengikuti perkembangan teknologi. Pengimplementasian sistem dalam perusahaan dapat dipetakan pada gambar dibawah ini: 


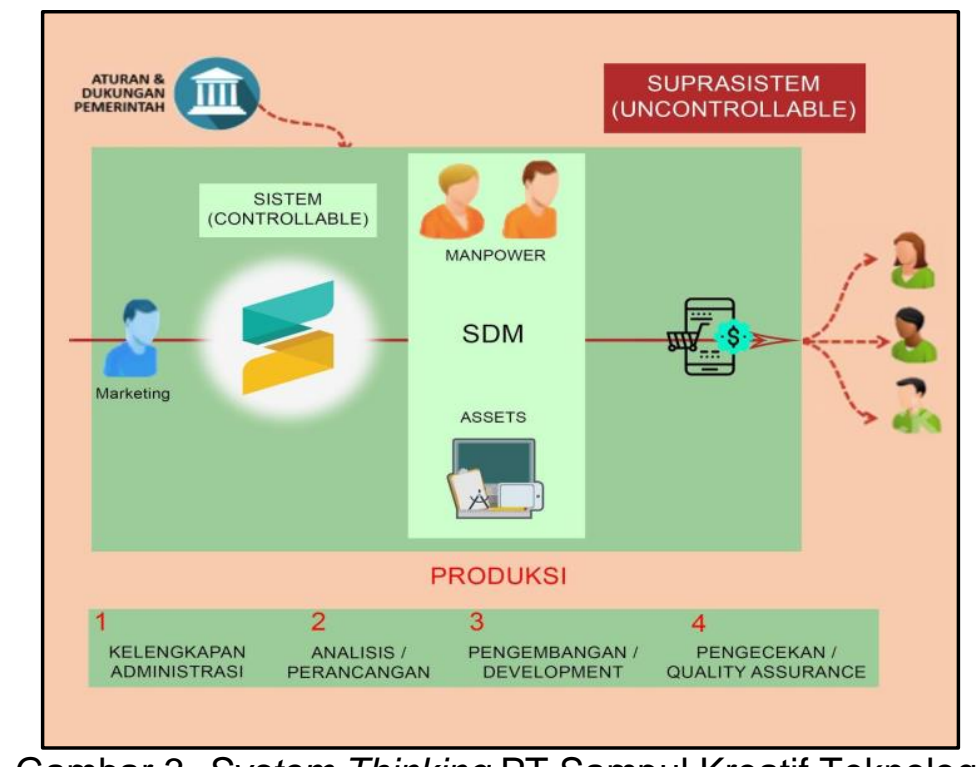

Gambar 3. System Thinking PT Sampul Kreatif Teknologi

Sistem yang ada di dalam perusahaan dimulai dengan sistem pemasaran (marketing) yang diakhiri dengan perolehan hasil atau benefits atau outcome dari klien perusahaan. Strategi pemasaran yang dilakukan oleh perusahaan adalah sebagai berikut:

Tabel 2. Strategi pemasaran perusahaan

\begin{tabular}{ll}
\hline \multicolumn{1}{c}{ OFFLINE } & \multicolumn{1}{c}{ ONLINE } \\
\hline $\begin{array}{l}\text { Penerimaan anak PKL atau } \\
\text { Magang atau Peneliti }\end{array}$ & Website \\
$\begin{array}{l}\text { Guru tamu, narasumber di sekolah } \\
\text { atau universitas atau perusahaan }\end{array}$ & Media Sosial \\
\hline
\end{tabular}

Perusahaan membagi sumber daya mereka kedalam tiga buah kelompok utama yang diantaranya adalah assets perusahaan sebagai kelompok pertama yang merupakan barang gerak atau barang tidak gerak yang dimiliki oleh perusahaan seperti bangunan barang-barang kantor dan mesin produksi (laptop, device, printer), kedua adalah pegawai sebagai kelompok sumber daya kedua dimana pegawai terampil yang dimiliki perusahaan adalah aset berharga yang dimiliki, karena menurut perusahaan bila ketidak tersediaan mereka dapat menghentikan kegiatan bisnis. Oleh karena itu kesejahteraan pegawai untuk mendapatkan fasilitas terbaik selalu diberikan oleh perusahaan. Terakhir adanya sistem (keilmuan), sistem yang dimiliki perusahaan adalah buah dari pemikiran panjang yang dimiliki oleh para pengembangnya, oleh karena itu keilmuan untuk mengelola perusahaan menggunakan sistem yang baik adalah suatu aset yang tidak mungkin dipungkiri peranannya.

Setelah pengidentifikasian ciri-ciri sistem telah dimiliki oleh perusahaan, maka tahapan selanjutnya mengukur keefektifan sistem. Pada penelitian ini, peneliti melakukan pengukuran sistem yang terdapat di dalam perusahaan menggunakan teknik pengukuran analisis korelasi parsial, dimana pengukuran dilakukan untuk melihat korelasi antara satu variabel terhadap variabel lainnya sehingga dapat menjadi acuan untuk mengukur seberapa efektifkah pengaruh system thinking terhadap benefit atau pendapatan yang mampu dihasilkan bagi perusahaan. Korelasi parsial digunakan untuk mengetahui efektifitas antara variabel produk perangkat lunak 
yang telah diproduksi oleh perusahaan sebagai output (X1) dengan keuntungan sebagai benefit (X2) bagi perusahaan akibat adanya penerapan sistem (Y) secara parsial, oleh karena itu digunakan rumus berikut:

$$
\tau=\frac{n \sum \chi \gamma-\left(\sum \chi\right)\left(\sum \gamma\right)}{\sqrt{\left\{n \sum \chi^{2}-\left(\sum \chi\right)^{2}\right\}\left\{n \sum \gamma^{2}-\left(\sum \gamma\right)^{2}\right\}}}
$$

Berikut tabel korelasi parsial untuk mengukur sistem ditinjau dari persentase keberhasilan proyek yang telah dilakukan oleh perusahaan dengan rata-rata keuntungannya.

Tabel 3. Korelasi parsial untuk mengukur sistem

\begin{tabular}{lrr}
\hline \multicolumn{1}{c}{ Perangkat Lunak } & $\begin{array}{c}\text { Persentase } \\
\text { Keberhasilan } \\
\mathbf{X}_{\mathbf{1}}(\%)\end{array}$ & $\begin{array}{c}\text { Rata-rata Keuntungan } \\
\mathbf{X}_{\mathbf{2}} \text { (Rp) }\end{array}$ \\
\hline Linen \& Lace & 60 & $1.000 .000,-$ \\
Masjid Kita & 30 & $1.000 .000,-$ \\
PERUM Taman SOKA & 40 & $5.000 .000,-$ \\
WARETORY & 70 & $20.000 .000,-$ \\
Psikolingua & 96 & $30.000 .000,-$ \\
Ren2Go & 90 & $50.000 .000,-$ \\
SegarMart & 80 & $30.000 .000,-$ \\
\hline
\end{tabular}

Merujuk pada teori manajemen sistem yang ditulis oleh (Schoderbek, 1980) dari hasil analisis korelasi parsial didapatkan korelasi antara produk perangkat lunak yang telah diproduksi dengan pendapatan perusahaan adalah 0,85 . Hal ini menunjukkan bahwa terjadi hubungan yang sangat kuat atau sangat efektif di antara produk perangkat lunak dengan pendapatan yang diperoleh perusahaan.

\section{Simpulan dan Saran}

Tahapan produksi yang dilakukan perusahaan menghasilkan produk jasa yang dapat bersaing dengan kompetitor, dibuktikan dengan hasil pengukuran produk perangkat lunak yang telah diproduksi dengan keuntungan perusahaan akibat adanya penerapan system thinking yang ditunjukkan dengan ciri-ciri yang dimilikinya. Daya juang perusahaan dalam ketahanan menempuh berbagai persoalan hingga mencapai waktu tujuh tahun menghasilkan hubungan yang sangat kuat. Hal tersebut adalah buah dari pengembangan system thinking yang baik yang diimplementasikan dan dijaga keberlangsungannya. Berkat kerja sama yang telah dilakukan oleh berbagai elemen perusahaan dan pengimplementasian system thinking, diharapkan mampu mewujudkan tujuan manifes yang telah tertuang di dalam visi dan misi perusahaan.

Penelitian ini tentunya memiliki kekurangan, sehingga peneliti selanjutnya diharapkan akan mampu melengkapi penelitian yang telah dilakukan di dalam penelitian ini. Penulis memiliki saran untuk penelitian selanjutnya agar jumlah UMKM yang diteliti ditambahkan dengan tujuan untuk menjelaskan penggunaan system thinking di dalam UMKM lebih menyeluruh secara umum serta 
variabel pengukuran sistem (system measurement) ditambahkan sebagai bahan penelitian, contohnya pengukuran efisiensi perusahaan dalam menerapkan sistem. Hal ini dapat ditinjau dari pengukuran barang mentah yang diterima dari supplier sebagai input kemudian dampaknya terhadap produk jadi sebagai output. Pengukuran dapat dilakukan menggunakan berbagai macam teknik, baik teknik identity atau korelasi parsial.

\section{Daftar Pustaka}

Abercrombie, N., Hill, S., \& Turner, B. S. (2010). Kamus Sosiologi. terj. Desi Noviyani. Yogyakarta: Pustaka Pelajar.

Al Fatta, H. (2007). Analisis dan Perancangan Sistem Informasi untuk keunggulan bersaing perusahaan dan organisasi modern. Penerbit Andi.

Anderson, V., \& Johnson, L. (1997). Systems thinking basics. In Waupaca.Uwex.Edu. Cambridge, Mass. : Pegasus Communications, (C1997. http://waupaca.uwex.edu/files/2011/01/Systems-Thinking2010.pdf\%5Cnpapers2://publication/uuid/A246BD33-722A-4890-9ED3-571E76ADA233

Hunger, J. D. (2020). Essentials of strategic management.

Imbayani, I. G. A., \& Endiana, I. D. M. (2016). Pengaruh Pemahaman dan Penerapan Sistem Informasi Terhadap Kinerja UMKM Pengrajin Genteng di Kabupaten Tabanan. Jurnal IImu Manajemen (JUIMA), 6(1).

Kusmayadi, D. (2008). Pengaruh Lingkungan Bisnis Terhadap Kinerja Perusahaan: Sebuah Tinjauan Teoritis Dan Empiris. Jurnal Akuntansi FE Unsil, 3(2), 431.

Kuswarno, E. (2001). Efektivitas Komunikasi Organisasi. Mediator: Jurnal Komunikasi, 2(1), 5561.

Prastika, N. E., \& Purnomo, D. E. (2019). Pengaruh Sistem Informasi Akuntansi Terhadap Kinerja Perusahaan Pada Usaha Mikro Kecil dan Menengah (UMKM) di Kota Pekalongan. Jurnal LITBANG Kota Pekalongan, 7.

Rogers, E. M. (1976). Rekha Agarwala Rogers. Communications in Organizations," Free Press, New York, NY.

Sakeon, T., \& Uhing, J. (2019). PENGARUH REKRUITMEN, SELEKSI, DAN KARAKTERISTIK INDIVIDU TERHADAP KINERJA PEGAWAI BANK SULUTGO KANTOR CABANG UTAMA MANADO. Jurnal EMBA: Jurnal Riset Ekonomi, Manajemen, Bisnis Dan Akuntansi, 7(4).

Schoderbek, C. G. (1980). Peter P. Schoderbek and Asterios G. Kefalas. Management Systems Conceptual Considerations. Dallas TX: Business Publications, Inc.

Suaryana, I. G. A. (2014). Pengaruh Penerapan Sistem Informasi Akuntansi Terhadap Kinerja Individu Pada Usaha Kecil Dan Menengah Di Nusa Penida. E-Jurnal Akuntansi, 8(1), 1426.

Telussa, A. M., Persulessy, E. R., \& Leleury, Z. A. (2013). Penerapan analisis korelasi parsial untuk menentukan hubungan pelaksanaan fungsi manajemen kepegawaian dengan efektivitas kerja pegawai. BAREKENG: Jurnal IImu Matematika Dan Terapan, 7(1), 15-18. 